\title{
GeOTOURISM Potential OF LiBEREC GRANITE
}

\author{
Emil Drápela \\ Technical University of Liberec, Faculty of Science, Humanities and Education, \\ Department of Geography, \\ Komenského 2, 46005 Liberec 5, Czech Republic \\ e-mail: emil.drapela@tul.cz
}

\begin{abstract}
Liberec granite is one of the most iconic Czech rocks. It is highly aesthetic, its mining has a long tradition, an interesting history and it is currently used to make high-quality products. In the wider vicinity of Liberec, this rock creates many attractive rock formations. Nevertheless, its current presentation towards potential tourists is practically zero. The article analyzes the potential of individual topics related to Liberec granite to attract tourists. It also describes the strong elements on which it is possible to build future promotion. In the Discussion chapter, the virtual educational trail "The Story of Liberec Granite" is presented, which should hopefully help to promote this local product.
\end{abstract}

\section{Keywords}

Geoheritage; Good interpretation; Urban geotourism; Liberec granite; Sustainable tourism; Anthropogenic landforms.

\section{Introduction}

Liberec granite is a coarse-grained eruption that forms most of the subsoil of the city of Liberec. The characteristic light pink coloration is mainly caused by pink growths of potassium feldspar, which occupy up to half of the rock volume. Their shape is usually thickly tabular; the sections of the largest outgrowths reach dimensions about $3 \times 2 \mathrm{~cm}$. In addition to potassium feldspar, the coarse-grained base material also contains sodium-calcium feldspar, quartz, biotite and amphibole, muscovite and, in small quantities, zirconium, apatite, titanite, mercury, magnetite and pyrite. Its age was dated to 319.52.3 Ma [1]. According to the current state of knowledge [1-4], it was formed during the slow solidification of magma during Variscan orogenesis within processes in the Krkonoše-Jizera plutonic complex.

At present, Liberec granite rises to the surface in a long strip bordering the Jizera Mountains from the west, south and southeast. But interestingly enough, although this rock is named after the regional capital of Liberec, its holotype lies in the adjacent Jablonec nad Nisou. The core of the Jizera Mountains is formed by the Jizera granite, which is very similar to Liberec granite - the difference between them is that the Jizera granite has an even coarser porphyric structure. Thanks to its physical properties, Liberec granite forms attractive rock outcrops on the surface, which are sought after by tourists and climbers. In addition, a number of buildings in the Jizera Mountains and nearby towns are built of Liberec granite, which thus co-creates the genius loci of these places. It is therefore surprising that there are practically no tourism products that take advantage of this strong local element.

One of the forms of sustainable tourism is geotourism. In recent decades, geotourism has been on the rise and is trying gradually to present lesser-known topics and localities. The basic principles of geotourism are defined in the Arouca declaration [5], which emphasizes the effort to connect the themes of inanimate nature, living nature and cultural-historical 
components. This is called the ABC approach (abiotic-biotic-culture). From the point of view of geotourism, Liberec granite is an exclusive topic, as in all three areas of the ABC model it has strong themes that can attract the classic heritage tourist. Due to the current absence of promotion of this topic, an analysis of the geotourism potential of Liberec Granite was created, which aimed to specify what exactly and how it would be appropriate to present to tourists. This analysis is the content of this article, and in addition to the principles of geotourism, defined by the European and Global Geoparks Network, it is also based on the theory of good interpretation.

\section{Research Objectives}

The main aim of this article is to assess whether Liberec granite, as a topic that combines elements of inanimate nature, living nature, culture and history, is a topic with tourist potential. The tourist potential is perceived as the ability to attract visitors and generate tourism in the region. It is therefore not a combination of localization, implementation and selective assumptions of tourism, but rather qualitative parameters of the topic, assessed according to the principles of the theory of good interpretation.

The secondary research goal is the identification of stories related to the topic of Liberec granite, which have a high potential in terms of the theory of good interpretation. These stories are the key to successfully reaching visitors who, if they are interested in the story, will start looking for more information on the topic, visiting more locations and spending more time in the region. Thanks to the fact that Liberec granite in the wider vicinity of the city of Liberec connects dozens of lesser-known tourist destinations, finding interesting stories can help with the promotion of these localities.

\section{Theoretical Background}

In 1957, Freeman Tilden's book “Interpreting our Heritage" [6] was published, which revised the view how to interpret and popularize professional topics to the public. His "craft of interpretation" was defined in this book by six basic principles, which were expanded and specified in the works of other authors [7-11]. Over the following decades, the whole concept of thought emerged, which is now called the theory of good interpretation.

The main rules of this theory include influencing the visitor's emotions, bringing the situation closer to the visitor's personality or situations that they know, and using as many visitors' senses as possible. Each post or place should have one key message that the visitor should learn in the form of an interesting story. [12] When evaluating the potential of a certain object from the point of view of heritage tourism, it is therefore necessary to identify topics that could be of interest to tourists and which can be told in the form of an interesting story. This is, of course, easier for historical events than for geology, but even for geosites there are currently good practices that can turn geological and geomorphological topics into interesting stories.

The current practice of geotourism interpretation uses the knowledge of the theory of good interpretation and combines it with the $\mathrm{ABC}$ model (see above), which is the main idea of geotourism in general. The result is the connection of natural phenomena with the history and culture of the place or region. Thanks to this, various impacts of natural phenomena can be explained by the above-mentioned principles of good interpretation, as they can be related to human personality and experiences. This procedure is being developed today by many authors [12-17], and this article represents one of the examples of this type of interpretation. 


\section{$3 \quad$ Methodology}

Thanks to the fact that the city of Liberec and its surroundings contain a number of objects made of Liberec granite, which are attractive for tourists, there was an initiative to bring this topic closer to an average tourist. For this reason, it was necessary to perform an input analysis in terms of the theory of good interpretation, which would evaluate the potential of individual topics related to Liberec granite and their interest to tourists.

In the first phase, topics related to Liberec granite were defined - from its origin to artistic use. Then it was verified on real excursions with a guide, to what extent these topics interest the target group. In this way, topics that have a geotourism potential were selected and less interesting topics were abandoned. Verification took place at the following events:

a) geotourism excursions within the Czech-Saxon project GECON - geological cross-border cooperation network (2017-2020, target group: adults interested in geology)

b) geotourism excursions within the Czech-Polish project GECON - geological cross-border cooperation network (2018-2020, target group: adults interested in geology)

c) excursions with university students of geography (2017-2020, target group: 19-25 years)

d) excursions with secondary school students from Liberec and Jablonec nad Nisou (20192020, target group: $12-16$ years)

e) ad-hoc excursions realized for the needs of the above-mentioned evaluation during the creation of the virtual educational trail "The Story of Liberec Granite" (2019-2020, target group: adults)

The evaluation and selection of catchy topics took place on the basis of obvious interest or a lack of interest during the interpretation of the guide. The method is, of course, based to some extent on the subjective feeling from the course of excursions. On the other hand, it should be noted that the number of people addressed by these excursions is in hundreds (the exact number is not known), which somewhat suppresses the influence of subjectivity. In addition, certain innovations have already been incorporated into newer excursions, which have subsequently been received with greater enthusiasm than the older ones. This also indicates a suitable selection of topics and their interesting interpretation.

\section{$4 \quad$ Results}

Before the results of the analysis itself are presented, it is necessary to introduce the topic of Liberec granite in the context of localities that can be used for geotourism. Thanks to the fact that Liberec granite is a very aesthetic rock, all places where it can be seen in a polished section are relatively attractive (Fig. 1A). Thanks to this, it is possible to connect a visit to various important buildings in the region with this topic. Furthermore, in the Liberec region there are a number of works of art made of Liberec granite (Fig. 1B), although most of them are smaller works.

The southern and western slopes of the Jizera Mountains are covered with hundreds of rock formations from Liberec granite (Fig. 1C; and the rest of the mountains from the Jizera granite, which is very similar) and there are a number of interesting technical constructions using this material (Fig. 1D). It can therefore be said that this is a topic that covers a number of lesser-known tourist destinations in the region. 

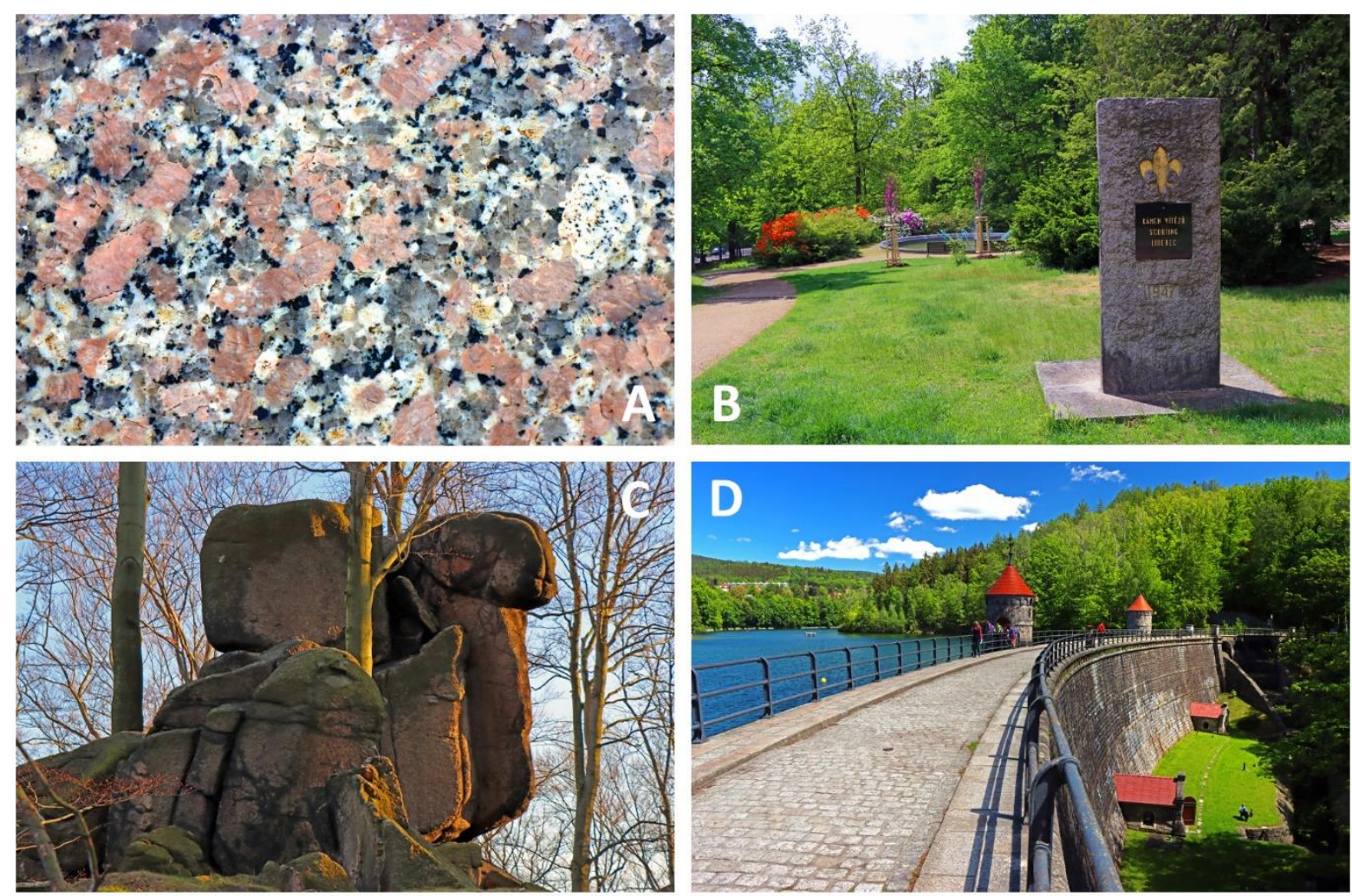

Source: Own processing

Fig. 1: Liberec granite: (A) detail of rock structure; (B) an example of artistic use - Scout Memorial in Lidové sady, Liberec; (C) an example of a rocky outcrop - Camel near Oldřichov v Hájich; (D) example of technical construction - Harcov dam in Liberec

The main findings of the evaluation are shown in Table 1. Each topic can be covered with one or more story-creating questions that form the structure of an excursion or promotional material. The questions listed in the table are the ones that most interested people during the excursions. The second important part of the experience, however, is the interpretation itself, whether it is given by a guide or is written in a brochure or leaflet. Here, it is important to simplify the explanation into a clear message that can be expressed in one sentence. Of course, this does not mean that the guide should answer this question in one sentence, it is only important that they do not go into too much detail. The last column lists the tools that bring the topic closer to the visitor by referring to objects or experiences that the visitor knows. It is easier to imagine cooling of potato goulash than cooling of mixture of silicates, carbonates and aluminum compounds. These examples of real-life things make the interpretation much more lively and better received by visitors. 
Tab. 1: Evaluation of the geotourism potential of topics related to Liberec granite (LG)

\begin{tabular}{|c|c|c|c|}
\hline Topic & $\begin{array}{l}\text { Story-creating } \\
\text { question }\end{array}$ & $\begin{array}{l}\text { Answer simplified into one } \\
\text { sentence }\end{array}$ & $\begin{array}{l}\text { Possible explanation } \\
\text { tool }\end{array}$ \\
\hline \multirow[t]{3}{*}{ Origin } & $\begin{array}{l}\text { What does LG look } \\
\text { like? }\end{array}$ & $\begin{array}{l}\mathrm{LG} \text { is a rock containing pink and } \\
\text { white feldspar, gray quartz and } \\
\text { black mica and tourmaline. }\end{array}$ & white pudding \\
\hline & $\begin{array}{l}\text { Why are there big } \\
\text { crystals in LG? }\end{array}$ & $\begin{array}{l}\text { Large crystals were formed due to } \\
\text { the very long solidification of the } \\
\text { rock. }\end{array}$ & potato goulash \\
\hline & $\begin{array}{l}\text { How did LG come } \\
\text { into being? }\end{array}$ & $\begin{array}{l}\text { LG was formed by the gradual } \\
\text { solidification of hot magma at } \\
\text { great depths below the Earth's } \\
\text { surface. }\end{array}$ & cabbage soup \\
\hline \multirow[t]{3}{*}{ Properties } & How durable is LG? & $\begin{array}{l}\text { Very, many times more than most } \\
\text { other rocks. }\end{array}$ & $\begin{array}{l}\text { comparison with } \\
\text { walnut }\end{array}$ \\
\hline & $\begin{array}{l}\text { How can LG } \\
\text { disappear? }\end{array}$ & $\begin{array}{l}\text { Through erosion, when the rock is } \\
\text { broken down into grains of } \\
\text { individual minerals. }\end{array}$ & $\begin{array}{l}\text { young and old } \\
\text { mountains }\end{array}$ \\
\hline & How is LG mined? & $\begin{array}{l}\text { With a small amount of explosive } \\
\text { and knowledge of crystal growth } \\
\text { in the rock, a block of rock is } \\
\text { broken off. }\end{array}$ & slicing meat \\
\hline \multirow[t]{4}{*}{ Usage } & What is LG used for? & $\begin{array}{l}\text { It is used as a building and } \\
\text { decorative stone. }\end{array}$ & pavement, dams \\
\hline & $\begin{array}{l}\text { Are there any famous } \\
\text { buildings or } \\
\text { monuments from LG? }\end{array}$ & Yes, there are many examples. & Prague metro \\
\hline & $\begin{array}{l}\text { Has LG been used for } \\
\text { something interesting } \\
\text { in the past? }\end{array}$ & $\begin{array}{l}\text { For example, large monuments } \\
\text { from the times of Nazism and } \\
\text { Communism. }\end{array}$ & Stalin's monument \\
\hline & $\begin{array}{l}\text { Can I see any mining } \\
\text { remains around me? }\end{array}$ & $\begin{array}{l}\text { Yes, there are dozens of extinct } \\
\text { quarries right in Liberec. }\end{array}$ & digital terrain model \\
\hline \multirow[t]{3}{*}{ Landscape } & $\begin{array}{l}\text { Can I recognize LG in } \\
\text { the landscape? }\end{array}$ & $\begin{array}{l}\text { Yes, for example, LG rock } \\
\text { formations have a different shape } \\
\text { than sandstone. }\end{array}$ & $\begin{array}{l}\text { rocks in the Jizera } \\
\text { Mountains }\end{array}$ \\
\hline & $\begin{array}{l}\text { Does the LG subsoil } \\
\text { mean anything to the } \\
\text { biota on the surface? }\end{array}$ & $\begin{array}{l}\text { Yes, especially the very low water } \\
\text { absorption, thanks to which there } \\
\text { are peat bogs in the Jizera } \\
\text { Mountains. }\end{array}$ & peat bogs \\
\hline & $\begin{array}{l}\text { What affect the } \\
\text { mountains formed by } \\
\text { LG? }\end{array}$ & $\begin{array}{l}\text { Everything - climate, biota, } \\
\text { agriculture, industry etc. }\end{array}$ & weather in Liberec \\
\hline Tectonics & $\begin{array}{l}\text { When LG formed in } \\
\text { the depths, what } \\
\text { happened to be on the } \\
\text { surface? }\end{array}$ & $\begin{array}{l}\text { It is due to hundreds of millions of } \\
\text { years of erosion and movements } \\
\text { along geological faults. }\end{array}$ & $\begin{array}{l}\text { sandpit on the } \\
\text { playground }\end{array}$ \\
\hline
\end{tabular}


Current works studying geotourism deal mainly with issues of their protection [18-20] or assessment of their value [21-24]; fewer articles deal with the issue of interpretation [12-16]. However, it is the form of interpretation that most influences the visitor's experience of the geosite. There are currently 9 national geoparks in the Czech Republic, but their contribution to the region varies greatly - from a significant revival of the local tourist offer to almost zero. In addition to financial and organizational matters, this result is influenced by the quality of the interpretation of the local geological heritage, when geoparks, which strive to constantly improve in new and attractive forms of interpretation, are the successful ones. When interpreting, it is then necessary to be clear what topics have the potential to attract tourists and address them. Based on the analysis performed in this article, it is possible to assume that the topic of Liberec granite could have this potential.

Liberec granite co-creates an attractive landscape in the vicinity of Liberec and is used on many interesting buildings, works of art and technical structures in the region. The genius loci of the Jizera Mountains is largely conditioned by their granite subsoil, as well as the appearance of the cities in their foothills. A significant positive fact is that the theme of Liberec granite connects a number of lesser-known tourist destinations that can be promoted in this way. The fact that this is a very interesting topic can be deduced also from the design of a trilateral geopark with the provisional name Neisseland [17], which should be established in the future near the Czech-German-Polish border and where Liberec granite is one of the main points.

Whether the topic of Liberec granite really has geotourism potential will be seen in the near future. The project of the virtual educational trail "The Story of Liberec Granite", which should popularize this topic, is currently being completed. This virtual nature trail will be available on the website geostezka.tul.cz and in printed form at the Tourist Information Center in Liberec and the North Bohemian Museum. At seven stops, the visitor will walk a route about $4 \mathrm{~km}$ long, while at each stop, in addition to the text and accompanying pictures, they will also have a short video with an explanation of the guide. The trail is intended for the public for tourist purposes and schools for educational purposes. Depending on the access to the website, it will then be possible to analyze traffic data and supplement the analysis presented in this article with data from the field.

\section{Conclusion}

Liberec granite is a topic that connects inanimate nature, living nature, local culture and history - exactly as required by the current concept of geotourism. It is a phenomenon that affects a wide region and co-creates the uniqueness of local conditions. For this reason alone, it should be a topic that is communicated to visitors to the region. In addition, it is a topic that connects a number of lesser-known tourist destinations that could be promoted through this connecting theme. It would therefore seem that this is a great opportunity for the Liberec region, which is very popular with tourists in the Czech Republic. Nevertheless, you will probably not read about Liberec granite in the tourist materials at all, because the local authorities do not know how to promote it.

This article aimed to present a certain evaluation of the tourist potential of Liberec granite, based on the identification of key topics for good interpretation. The response of the participants of various excursions with the theme of Liberec granite was used as background data. Based on the feedback from the participants, topics were identified that have the potential to create catchy stories that will interest tourists. The results showed that there is definitely a potential to attract visitors, but it is necessary to grasp it correctly using the 
principles of good interpretation. The first attempt at this interpretation is the virtual educational trail "The Story of Liberec Granite", which should be completed before the end of 2020. Only after the first years of operation of this trail it will be possible to quantitatively evaluate how many visitors to the Liberec region were addressed by the topic of Liberec granite.

\section{Acknowledgements}

This article was created thanks to the project "Geodiversity within urban areas: perception, function, potential". Funding Agency: Technology Agency of the Czech Republic. Grant Number: TL02000219.

\section{Literature}

[1] ŽÁK, J.; VERNER, K.; SLÁMA, J.; KACHLÍK, V.; CHLUPÁČOVÁ, M.: Multistage magma emplacement and progressive strain accumulation in the shallow- level Krkonoše- Jizera plutonic complex, Bohemian Massif. Tectonics. DOI: $10.1002 /$ tect.20088

[2] ŽÁK, J.; KLOMÍNSKÝ, J.: Magmatic structures in the Krkonoše-Jizera Plutonic Complex, Bohemian Massif: evidence for localized multiphase flow and small-scale thermal-mechanical instabilities in a granitic magma chamber. Journal of Volcanology and Geothermal Research. DOI: 10.1016/j.jvolgeores.2007.05.006

[3] ADAMUSZEK, M.; JOHN, T.; DABROWSKI, M.; PODLADCHIKOV, Y. Y.; GERTISSER, R.: Assimilation and diffusion during xenolith-magma interaction: a case study of the Variscan Karkonosze Granite, Bohemian Massif. Mineralogy and Petrology. DOI: 10.1007/s00710-009-0088-8

[4] ZEL, I. Y.; PETRUŽÁLEK, M.; KICHANOV, S. E.; NAZAROV, K.; LOKAJÍČEK, T.; KOZLENKO, D. P.; TURKOVÁ, I.; KOTRLÝ, M.; ONYSKO, R.: Contribution of neutron tomography to 3D heterogeneity analysis of granitic rocks. Acta Geodynamica et Geomaterialia. DOI: 10.13168/AGG.2020.0019

[5] GLOBAL GEOPARKS NETWORK: Arouca Declaration on Geotourism November 12, 2011 Portugal. [online]. 2011. [accessed 2020-10-24]. Available from WWW: http://www.europeangeoparks.org/?p=223

[6] TILDEN, F.: Interpreting Our Heritage. The University of North Carolina Press, Chapell Hill, 1957. ISBN 9780807807200.

[7] HAM, S.: Environmental Interpretation. Fulcrum Publishing, Colorado, 1992. ISBN 1555919022.

[8] HAM, S.: Interpretation - Making a Difference on Purpose. Fulcrum Publishing, Golden CO, 2013. ISBN 1555917429.

[9] BECK, L.; CABLE, T.: Interpretation for the 21st Century: Fifteen Guiding Principles for Interpreting Nature and Culture. Sagamore Publishing, Champaign IL, 2002. ISBN 978-1-57167-1331.

[10] BECK, L.; CABLE, T.: The Gifts of Interpretation. Fifteen Guiding Principles for Interpreting Nature and Culture. Sagamore Publishing, Urbana IL, 2011. ISBN 978-157167-636-8. 
[11] BROCHU, L.: Interpretative Planning: The 5-M Model for Successful Planning Projects. Fort Collins: National Association for Interpretation, Fort Collins, 2003. ISBN 1879931311.

[12] DRÁPELA, E.; BÖHM, H.: Interpretation of secondary geodiversity: Experience from geotouristic guide practice. In: Fialová, J. (ed.), Public Recreation and Landscape Protection - With Sense Hand in Hand? Mendel University in Brno, Krrtiny, 2020, pp. 235-238. ISBN 978-80-7509-715-6.

[13] HOSE, T. A.: 3G's for Modern Geotourism. Geoheritage. DOI: 10.1007/s12371-011$\underline{0052-y}$

[14] NECHEŞ, I.-M.: Geodiversity beyond material evidence: a Geosite Type based interpretation of geological heritage. Proceedings of the Geologists' Association. DOI: $10.1016 /$ j.pgeola.2015.12.009

[15] MIGOŃ, P.; PIJET-MIGOŃ, E..: Natural Disasters, Geotourism, and Geointerpretation. Geoheritage. DOI: $\underline{10.1007 / \mathrm{s} 12371-018-0316-\mathrm{x}}$

[16] ROBERTSON, M. H.: Heritage interpretation, place branding and experiential marketing in the destination management of geotourism sites. Translation Spaces. DOI: $\underline{10.1075 / \text { ts.4.2.06rob }}$

[17] DRÁPELA, E., BÜCHNER, J.: Neisseland Geopark: Concept, Purpose and Role in Promoting Sustainable Tourism. In: Fialová, J. (ed.), Public Recreation and Landscape Protection - With Sense Hand in Hand? Mendel University in Brno, Křtiny, 2020, pp. 268-272. ISBN 978-80-7509-659-3.

[18] GRAF, W. L.: Damage Control: Restoring the Physical Integrity of America's Rivers. Annals of the Association of American Geographers. DOI: 10.1111/0004-5608.00231

[19] SOLARSKA, A.; HOSE, T. A.; VASILJEVIĆ, D. A.; MROCZEK, P.; JARY, Z.; MARKOVIĆ, S. B.; WIDAWSKI, K.: Geodiversity of the loess regions in Poland: Inventory, geoconservation issues, and geotourism potential. Quaternary International. DOI: $10.1016 /$ j.quaint.2012.08.2057

[20] KIERNAN, K.: The Nature Conservation, Geotourism and Poverty Reduction Nexus in Developing Countries: A Case Study from the Lao PDR. Geoheritage. DOI: $\underline{10.1007 / \mathrm{s} 12371-013-0084-6}$

[21] BRILHA, J.: Inventory and Quantitative Assessment of Geosites and Geodiversity Sites: a Review. Geoheritage. DOI: 10.1007/s12371-014-0139-3

[22] FASSOULAS, Ch.; MOURIKI, D.; DIMITRIOU-NIKOLAKIS, P.; ILIOPOULOS, G.: Quantitative Assessment of Geotopes as an Effective Tool for Geoheritage Management. Geoheritage. DOI: 10.1007/s12371-011-0046-9

[23] KUBALÍKOVÁ, L.; KIRCHNER, K.: Geosite and Geomorphosite Assessment as a Tool for Geoconservation and Geotourism Purposes: a Case Study from Vizovická vrchovina Highland (Eastern Part of the Czech Republic). Geoheritage. DOI: $10.1007 / \mathrm{s} 12371-015-0143-2$

[24] ŠTRBA, L., KRŠÁK, B., SIDOR, C.: Some Comments to Geosite Assessment, Visitors, and Geotourism Sustainability. Sustainability. DOI: 10.3390/su10082589

Mgr. Emil Drápela, Ph.D. 


\section{GEOTURISTICKÝ POTENCIÁL LIBERECKÉ ŽULY}

Liberecká žula je jednou z nejikoničtějších českých hornin. Je vysoce estetická, její těžba má tradici, zajímavou historii a produkty $\mathrm{z}$ ní vysokou kvalitu. $\mathrm{V}$ širším okolí Liberce tato hornina vytvárí mnoho atraktivních skalních útvarů. Přesto její současná prezentace směrem k potenciálním turistům je prakticky nulová. Článek analyzuje potenciál jednotlivých témat spojených s libereckou žulou, navrhuje, jak zaujmout turisty, a popisuje silné prvky, na kterých je možné vybudovat budoucí propagaci. V závěru je představena virtuální naučná stezka Př́iběh liberecké žuly, která by měla pomoci tento lokální produkt zpropagovat.

\section{GEOTOURISMUS-POTENZIAL VON REICHENBERGER GRANIT}

Reichenberger Granit ist einer der ikonischsten tschechischen Mineralen. Es ist sehr ästhetisch, sein Bergbau hat eine Tradition, interessante Geschichte und Produkte von hoher Qualität. In der weiteren Umgebung von Liberec/Reichenberg schafft dieser Felsen viele attraktive Felsformationen. Doch seine aktuelle Darstellung gegenüber potenziellen Touristen ist praktisch Null. Der Artikel analysiert das Potenzial einzelner Themen im Zusammenhang mit Reichenberger Granit, Touristen anzuziehen und beschreibt die starken Elemente, auf denen es möglich ist, zukünftige Propagation aus bauen. Am Ende wird ein virtueller Lehrpfad namens Die Geschichte von Reichenberger Granit vorgestellt, der dazu beitragen soll, dieses lokale Produkt zu fördern.

\section{POTENCJAE GEOTURYSTYCZNY LIBERECKIEGO GRANITU}

Liberecki granit jest jedną z najbardziej charakterystycznych czeskich skał. Jest bardzo estetyczny, jego wydobycie ma tradycję, ciekawą historię a produkty z niego wytwarzane są wysokiej jakości. W szerszej okolicy Liberca skała ta tworzy wiele atrakcyjnych formacji skalnych. Jednak obecnie nie jest prawie wcale prezentowana potencjalnym turystom. Artykut analizuje potencjał poszczególnych zagadnień związanych z libereckim granitem, proponując sposoby zainteresowania turystów i opisując mocne strony, na których można oprzeć promocję. $\mathrm{Na}$ zakończenie zaprezentowano wirtualną ścieżkę dydaktyczną pn. Historia libereckiego granitu, która powinna przyczynić się do wypromowania tego lokalnego produktu. 